\title{
THE CANADIAN JOURNAL OF COMMUNITY MENTAL HEALTH FROM 1982 TO 2006: A CONTENT ANALYSIS
}

\author{
LAURENCE FORTIN-PELLERIN, JOËLLE POULIOT-LAPOINTE, \\ CAROLINE THIBODEAU, and MARIE-HÉLÈNE GAGNÉ \\ École de psychologie, Université Laval, Quebec City
}

\begin{abstract}
This article presents a content analysis of articles published in the Canadian Journal of Coтmunity Mental Health (CJCMH) between 1982 and 2006. The analysis aims to provide an overall description of the articles, identify the major trends over time, and suggest future directions for CJCMH issues. The article highlights the development over time of various dimensions of CJCMH's content: identity and location of CJCMH's editors and most productive authors, language of publication, affiliation of the articles' first authors, themes of special issues and supplements, types of articles and areas of interest covered, and source of financing for empirical studies published in CJCMH. These findings are discussed in the context of the history and current knowledge of community mental health.
\end{abstract}

The role of an academic journal is to provide a means of communication within the research community and between researchers and practitioners. The main function of such a journal is to present the results of research relating to a particular field of expertise. Articles published in an academic journal serve as a means of measuring progress in an academic field, and at the same time reflect the interests and concerns of practitioners in the field covered by the journal. These characteristics make it worthwhile to analyze a journal's content (Buboltz \& Savickas, 1994).

The Canadian Journal of Community Mental Health (CJCMH) defines its mission as being able to provide

a much needed forum for Canadian scholars and practitioners with interest in the promotion of positive mental health and the prevention and treatment of mental health problems in community settings. The Journal is an interdisciplinary publication devoted to the sharing of information and valid knowledge about phenomena pertinent to the mental well-being of Canadians and their communities.

The authors would like to thank Francine Lavoie and Tim Aubry for their valuable feedback while this article was being prepared, the Canadian Journal of Community Mental Health for its financial support, and Jean-Michel Roy for his technical support. All correspondence concerning this article should be directed to Marie-Hélène Gagné, professeure, École de psychologie, Université Laval, Quebec City, QC G1K 7P4. E-mail: marie-helene.gagne@psy.ulaval.ca 
Since it began publication in 1982, CJCMH has given priority to articles related to the following areas of interest: social service organization, program evaluation, self-help, public education, training, consultation, social action, community development, assessment of community needs, and advocacy. CJCMH's bilingualism and interdisciplinary nature make it a unique publication in the community mental health field in Canada (Canadian Journal of Community Mental Health, 2001).

Community mental health refers to a set of attitudes and values relating to the study of human problems and their solutions (Kiely \& Moreau, 1975). While specifically concerned with mental health problems (Kiely \& Moreau, 1975), this field involves the study of the social, economic, and cultural factors (Bennett \& Trute, 1982) that, on the one hand, contribute to the emergence and persistence of these problems or, on the other hand, can mitigate them. In a community mental health perspective, individual deficiencies are considered the result of dysfunction in social settings such as school, workplace, and family. Hence, changing these settings to reduce the deficits manifested in individuals becomes a goal of community mental health (Morency, Couture, Johnson, \& Kiely, 1988). In this perspective, community mental health is based on eight fundamental values: autonomy, confidentiality, support, security, confidence, participation, solidarity, and social justice (Liégeois \& Audenhove, 2005).

A content analysis of CJCMH was carried out in 1993, after 10 years of publication. The following findings emerged from this analysis: (a) The majority of authors were men; (b) the majority of authors were affiliated with university or college settings; (c) non-empirical articles were more common than empirical articles; (d) among empirical articles, data collection involving face-to-face contact between researchers and participants were the most common; and (e) individual-level analysis was most common in the reviewed articles but more than half of the articles included multiple levels of analysis (Peirson \& Walsh-Bowers, 1993).

The present study is intended to follow up on this earlier analysis and to mark the 25th anniversary of CJCMH. Its aims are to provide an overall description of the articles published between 1982 and 2006, to identify trends over time, and to suggest future directions for the journal. At its annual meeting in May 2006, the CJCMH editorial team outlined this project and decided to support it. Three doctoral students in community psychology at Université Laval were assigned the task of analyzing the data and preparing an article based on the results.

\section{METHOD}

A content analysis was carried out in order to provide a comprehensive picture of material published in CJCMH. Content analysis is defined as a methodology for analyzing textual documents so as to identify their meanings or the ways in which they create meaning. There are two main types of content analysis. A quantitative analysis involves coding, tabulation, comparison, and the identification of trends. In a qualitative analysis, an exploration of the significance found in a text is sought (Mucchielli, 1996). In this case, the decision was made to undertake a quantitative content analysis. This method is especially useful when there is a large body of material to analyze (L'Écuyer, 1990), as is the case with 25 years' output of CJCMH. It provides the necessary scope for analysis and categorizing 


\section{CONTENT ANALYSIS}

material in a meaningful manner, allows for quantitative comparison between different elements or periods of time, and is conducive to a focused analysis (L'Écuyer, 1990).

\section{Data}

The data on which the present analysis is based are taken from the abstracts of the 495 articles published in CJCMH from 1982 through Spring 2006, including those published in special issues $(n=$ 236) and supplements $(n=49)$. Where necessary, the main body of an article was consulted to confirm or supplement information obtained from the abstract. Since the institutional affiliation of the first author and sources of financing for the research (if any) are not mentioned in the abstract, this information was collected elsewhere, generally from the first page of the article. Introductory articles for special issues, book reviews, and symposiums in which a number of authors were invited to express their point of view on the same subject were excluded from the data.

\section{Development of the Coding Table and Analytical Procedures}

In developing a table for coding the material, both the initial plan for the content analysis defined by the CJCMH editorial team and information available in the articles were taken into account. First, a preliminary version of the table was piloted by the three members of the research team. Using this instrument, they analyzed independently the data from eight abstracts, consulting each other when they encountered data that was unclear or difficult to interpret. As a result of this pilot, the research team concluded that it was not possible to do a systematic analysis of the disciplines of the authors whose work had been published in CJCMH, as the Journal had not collected this information. They reached the same conclusion with regard to the sex of the authors, which was too often difficult to determine on the basis of the provided author's name alone in articles, especially since in some cases only initials were used. As a result, the discipline and sex of authors of articles in CJCMH were analyzed only in the case of the Journal's editors and most prolific authors.

As the analysis proceeded, other modifications were made to the coding table. The "target population" dimension had to be abandoned. The diversity of populations targeted in the 495 articles made this dimension difficult to analyze either quantitatively or qualitatively. As well, analysis of the source of funding for the research reported in empirical articles had to be abandoned. In place of source of funding, only the indication of presence of research funding was coded. The final version of the coding table is included as an appendix.

Using the coding table, the three members of the research team coded the data with respect to the following dimensions: identity of the authors, institutional affiliation of the first author, type of article, area of interest (as presented in the CJCMH mission statement) covered by the article, language in which the article was written, and indication of the presence of research funding in empirical articles. The themes of special issues and supplements and the identity of CJCMH's editors were also tabulated. Much of this information is of a factual nature and did not involve judgment on the part of the research team. Other dimensions of the analysis, however, required more elaborate processes for interpreting data. 
Initially, the productivity of authors whose work had been published in CJCMH was calculated, using the mathematical formula developed by Howard, Cole, and Maxwell (1987). A number of content analyses of journal output have used this formula (Buboltz, Miller, \& Williams, 1999; Cokley, Caldwell, Miller, \& Muhammad, 2001; Loveland, Buboltz, Schwartz, \& Gibson, 2006; Pope-Davis, Ligiero, Liang, \& Codrington, 2001), which allows researchers to take into account both the number and the rank order of authors of a given article. Each article is assigned a total of 1 point, and the score assigned to each author varies with the number of authors. Thus, a score of 1 is assigned to the author of a sole-authored article. If there are two authors, the first author is assigned a score of 0.6 and the second a score of 0.4. The formula can be applied to an infinite number of authors.

Next, each article was categorized by article type: (a) empirical (qualitative or quantitative), (b) description of a community-based program of intervention, (c) literature review, or (d) theoretical. These dimensions were established on the basis of the main types of articles typically noted in content analyses of community journals (Novaco \& Monahan, 1980; Peirson \& Walsh-Bowers, 1993). Where there was doubt to which category an article belonged, members of the research team reviewed and discussed the article until consensus was achieved. Operational definitions of the article types are provided in an appendix.

Finally, the areas of interest identified in the CJCMH mission statement were incorporated into the analysis as categories for examining the themes covered by the articles: (a) social service organization, (b) program evaluation, (c) assessment of community needs, (d) community development, (e) consultation, (f) social action, (g) self-help, (h) public education and training, and (i) advocacy (Canadian Journal of Community Mental Health, 2001). An additional theme was identified in the course of the content analysis: public response to a particular phenomenon or group in the population. The areas of training and public education, which are very similar, were merged. As with article type, consensus among members of the research team was the approach used when there was doubt about the most appropriate category in which to place an article. Operational definitions of the themes are provided in an appendix.

\section{Comparison between the Present Content Analysis and the One Carried Out in 1993}

Two elements of published articles in the earlier content analysis carried out in 1993 (Peirson \& Walsh-Bowers, 1993) were examined again in the present analysis, mainly authors' affiliation and article type. The other elements covered in the 1993 analysis-authors' sex, collaboration between authors in joint publications, systemic level of analysis, population of interest, and relationship between researchers and participants-were not studied in the current content analysis, as a result of the large number of articles to analyze $(N=495)$ and the difficulty of collecting data on these elements on the basis of abstracts alone. On the other hand, new elements were added to the present analysis: a chronological tabulation of editors and of special issues and supplements, the productivity of authors whose work has been published in CJCMH, the presence of areas of interest for CJCMH in published articles, the language of publication of each article, and the presence of research funding for published empirical research. These elements provide information related to knowing "who" has had the most influence on the development and content of CJCMH and for determining the make-up of its content. 


\section{CONTENT ANALYSIS}

\section{RESULTS}

\section{Identity, Productivity, and Location of Influential Figures}

Editors. Table 1 provides a list of the editors of CJCMH since its inception. The editors' duties include co-ordinating the review of English and French manuscripts, providing guidance to the guest editors of special issues of CJCMH, and participating in a number of other managerial tasks. Hence, their influence on CJCMH's content is considerable. It is interesting to note that CJCMH has had 10 female and 9 male editors over time, which suggests that gender equity has been present. The editors have come from a variety of universities in four different provinces, with most of them coming from Ontario and Quebec. Among academic disciplines of editors, psychology $(n=10)$ and social work $(n=6)$ have been represented most frequently.

Authors. Since 1982, a total of 821 different authors have published in CJCMH. Table 2 lists the 11 most prolific authors over this period (two authors are tied for 10th position). Men and women are fairly equitably represented among these authors, although it was not possible to determine whether equity prevailed in the whole population of CJCMH authors. The most prolific authors have come from a variety of universities located in four different provinces, with most of them coming from

\section{Table 1}

Editors of CJCMH, 1982-2006

\begin{tabular}{llll}
\hline Years & Editor & Discipline & Affiliation \\
\hline $1982-90$ & Edward M. Bennett & Psychology & Wilfrid Laurier University \\
$1982-90$ & Barry Trute & Social work & University of Manitoba \\
1988 & Maurice Payette & Psychology & Université de Sherbrooke \\
$1989-92$ & Céline Mercier & Psychology & Douglas Hospital \\
$1990-94$ & Kathryn McCannell & Social work & University of British Columbia \\
$1990-96$ & Geoffrey Nelson & Psychology & Wilfrid Laurier University \\
$1992-95$ & Jacques Rhéaume & Sociology & Université du Québec à Montréal \\
$1994-99$ & Judy Lynam & Nursing & University of British Columbia \\
$1995-99$ & Francine Lavoie & Psychology & Université Laval \\
$1996-2001$ & Ed Pomeroy & Psychology & Brock University \\
1999 & Jérôme Guay & Psychology & Université Laval \\
$2000-2001$ & Annie Devault & Psychology & Université du Québec à Hull \\
$2000-2002$ & Paule McNicoll & Social work & University of British Columbia \\
$2002-4$ & Bernadette Dallaire & Social work & Université Laval \\
$2002-5$ & Diane Hiebert-Murphy & Social work & University of Manitoba \\
$2003-5$ & Marshall Fine & Social work & Wilfrid Laurier University \\
$2005-6$ & Marie-Hélène Gagné & Psychology & Université Laval \\
2006 & Tim Aubry & Psychology & University of Ottawa \\
2006 & Terry Krupa & Rehabilitation & Queen's University \\
\hline
\end{tabular}

Note. ${ }^{a}$ Département de communication sociale et publique, UQAM. 
Ontario and Quebec. The same trend can be seen in Table 3, which shows the five most common institutional affiliations of first authors of articles published in CJCMH, along with the proportion and frequency represented by each institution. However, almost three quarters of first authors came from Canadian or American universities or organizations other than these five, which suggests that authors have come from a wide variety of locations. Finally, $70.1 \%$ of first authors have been affiliated with academic institutions. First authors affiliated with non-academic institutions represent less than a third of CJCMH's output.

Table 2

CJCMH's Most Productive Authors

\begin{tabular}{llllrr}
\hline Rank & Discipline & Author & Affiliation & $\begin{array}{c}\text { Number } \\
\text { of articles }\end{array}$ & Weight \\
\hline 1 & Psychology & Geoffrey Nelson & Wilfrid Laurier University & 13 & 5.7 \\
2 & Psychology & Stewart Page & University of Windsor & 5 & 3.6 \\
3 & Psychology & Camil Bouchard & Université du Québec à Montréal & 5 & 3.4 \\
4 & Psychology & Céline Mercier & Douglas Hospital & 5 & 3.3 \\
5 & Sociology & Françoise Boudreau & York University & 4 & 3.2 \\
6 & Psychology & Sylvie Jutras & Université du Québec à Montréal & 4 & 2.9 \\
7 & Social work & Christopher Bagley & University of Calgary & 4 & 2.7 \\
8 & Social work & Leslie M. Tutty & University of Calgary & 4 & 2.6 \\
9 & Psychology & Francine Lavoie & Université Laval & 6 & 2.6 \\
10 & Social work & Barry Trute & University of Manitoba & 5 & 2.5 \\
10 & Psychology & Edward M. Bennett & Wilfrid Laurier University & 4 & 2.5 \\
\hline
\end{tabular}

Table 3

Main Institutional Affiliations of First Authors

\begin{tabular}{lcc}
\hline Affiliation & Proportion (\%) & Frequency \\
\hline Wilfrid Laurier University & 6.5 & 32 \\
Université de Montréal & 6.1 & 30 \\
Université Laval & 5.5 & 27 \\
University of Toronto & 4.6 & 23 \\
Université du Québec à Montréal & 4.4 & 22 \\
\hline
\end{tabular}

\section{Language of Publication}

A total of 490 articles were classified according to the language in which they were written. The five remaining articles appeared in a completely bilingual special issue: All the articles in that issue were published in both languages. Among the unilingual articles, two thirds were written in English and one third in French. During the initial 5 years of publication, French-language articles represented 


\section{CONTENT ANALYSIS}

$13 \%$ of the total. This proportion increased rapidly and has remained in the neighbourhood of 30\%: 29.5\% between 1987 and 1996, 33.8\% between 1997 and 2001, and 27.5\% between 2002 and 2006. Figure 1 illustrates this finding.

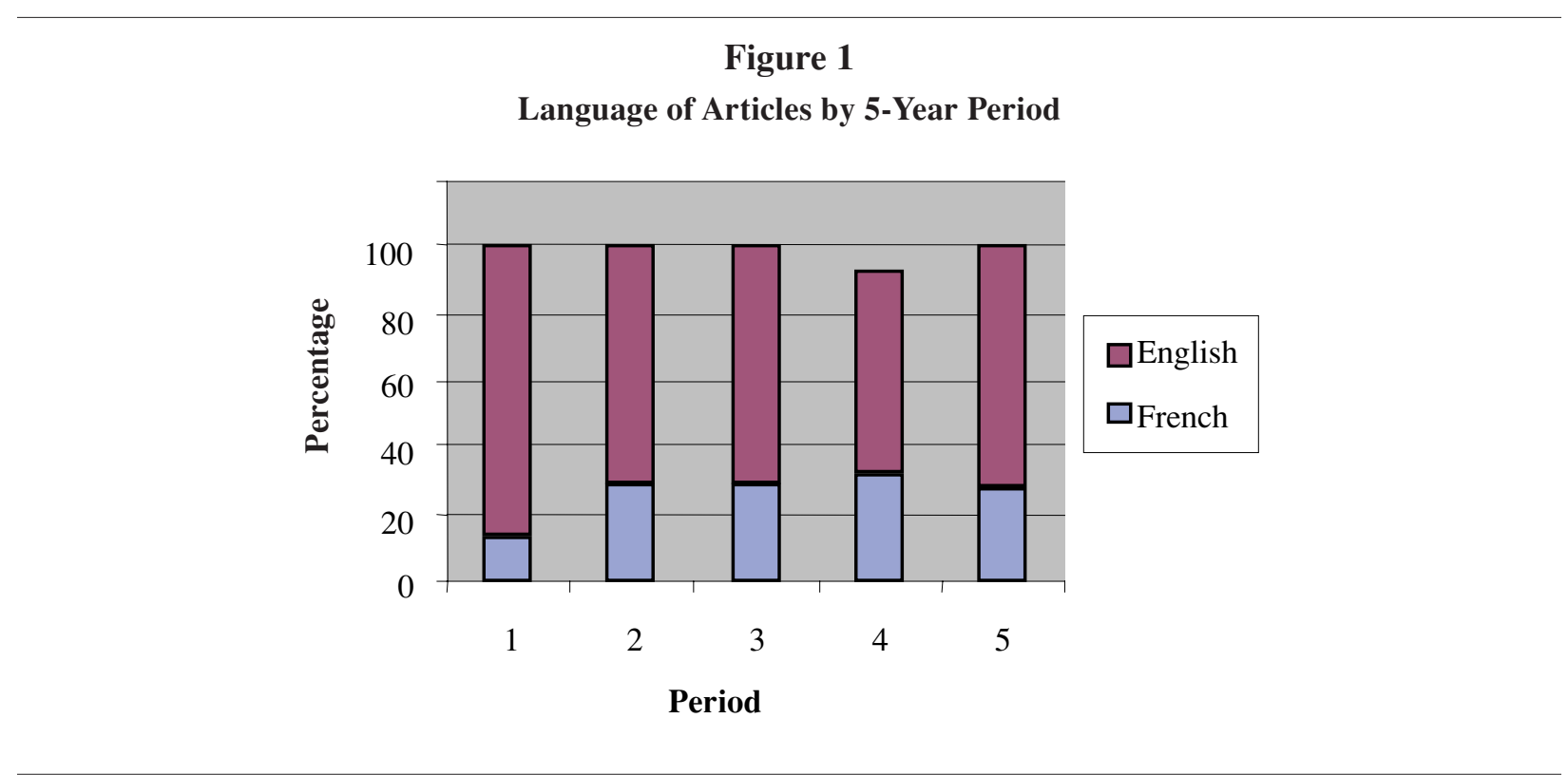

Note. $1=1982-86 ; 2=1987-91 ; 3=1992-96 ; 4=1997-2001 ; 5=2002-6$.

\section{Themes Covered and Types of Articles Published}

Special issues and supplements. CJCMH has published a special issue every year. The editorial team chooses the theme of the special issue and then appoints guest editors to be responsible for the publishing process. In addition, four supplements have been published: conference or workshop proceedings relevant to the community mental health field (1983 and 1998), a monograph on mental health legislation and community attitudes (1991), and the findings of a research project on family transitions relating to separation (2002).

The titles of CJCMH's special issues and supplements over 25 years are presented in Table 4. Almost half the issues deal with mental health directly. A number of CJCMH's areas of interest are represented in these issues, such as cultural diversity, violence against women, young offenders, and gay and lesbian issues.

Types of articles. More than half (54.3\%) of the articles published in CJCMH have been empirical. Theoretical articles are the second most common type (30.7\%), followed by descriptions of community programs $(8.5 \%)$ and literature reviews $(6.5 \%)$. The proportion of empirical articles has increased over time, from $34 \%$ in the first 5 years (1982-86) to $75 \%$ in the most recent 5 years (2002-6). Figure 2 illustrates this trend. 


\section{Table 4}

Titles of CJCMH Special Issues and Supplements, 1982-2005

\begin{tabular}{|c|c|}
\hline Year & Title \\
\hline 1982 & Community psychology in Canada \\
\hline \multirow[t]{2}{*}{1983} & Family health practice in Canada \\
\hline & $\begin{array}{l}\text { Special supplement: Psycho-social impacts of resource development in Canada: Research strategies and } \\
\text { applications }\end{array}$ \\
\hline 1984 & Education and training in Canadian human services \\
\hline 1985 & Program evaluation: A participatory approach \\
\hline 1986 & Women and mental health \\
\hline 1987 & Community mental health services for the chronically mentally disabled \\
\hline 1988 & Wife battering: A Canadian perspective \\
\hline 1989 & Public policy, social and economic development, and the power of ideas \\
\hline 1990 & Being disabled in Canada in the $1990 \mathrm{~s}$ \\
\hline \multirow[t]{2}{*}{1991} & Social support for the elderly and their caregivers \\
\hline & Special supplement: Community attitudes and mental health law \\
\hline 1992 & Work, private life, and mental health: The new role of the community \\
\hline 1993 & Cultural diversity: Voice, access, and involvement \\
\hline 1994 & Prevention: Focus on children and youth \\
\hline 1995 & Mutual-aid groups and support groups \\
\hline 1996 & Power and oppression in mental health \\
\hline 1997 & Mental health in Aboriginal communities \\
\hline \multirow[t]{2}{*}{1998} & Critical perspectives on applied ethics \\
\hline & Special supplement: Quality of life measurement in mental health \\
\hline 1999 & Positive innovations in mental health \\
\hline 2000 & Canadian community mental health: Our past, our future \\
\hline 2001 & Young offenders: Balancing control and treatment \\
\hline \multirow[t]{2}{*}{2002} & Innovation in community mental health: International perspectives \\
\hline & Special supplement: Family transitions related to parental separation \\
\hline 2003 & Disrupting normalcy: Lesbian, gay, queer issues and mental health \\
\hline 2004 & Globalization and community mental health \\
\hline 2005 & Aging and mental health \\
\hline
\end{tabular}


Figure 2

Types of Articles by 5-Year Period

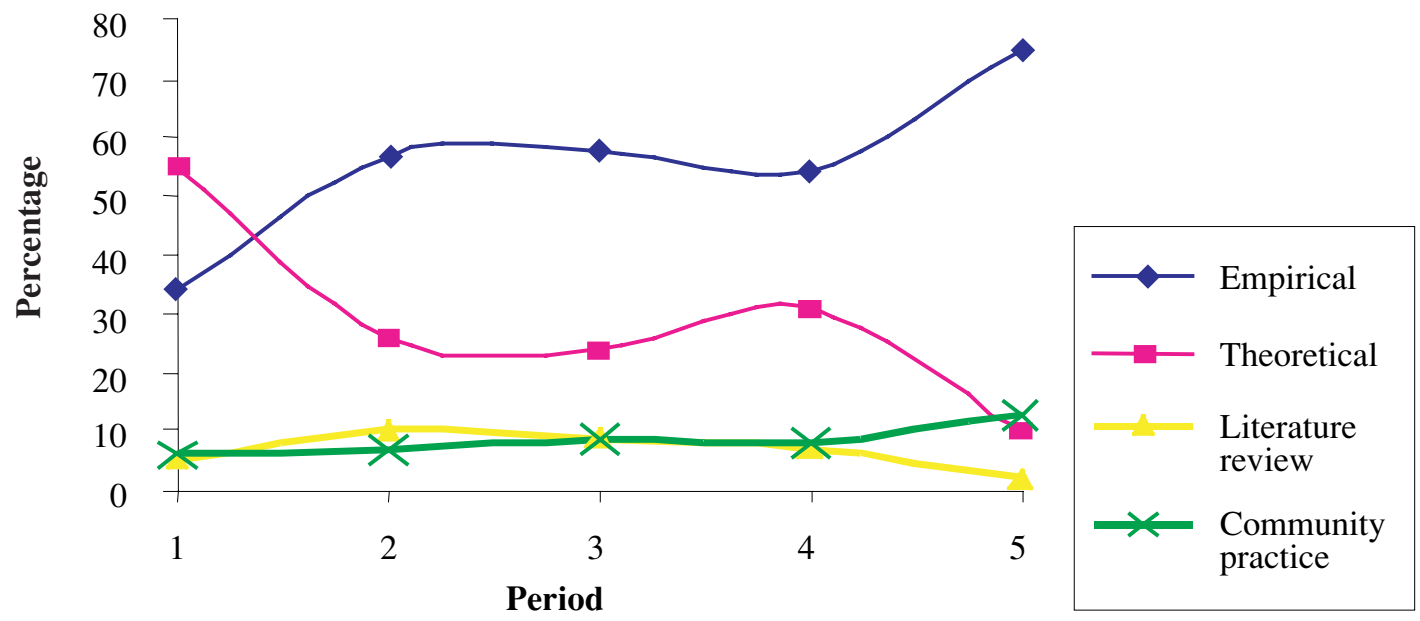

Note. $1=1982-86 ; 2=1987-91 ; 3=1992-96 ; 4=1997-2001 ; 5=2002-6$.

In Table 5, article type is presented as a function of the first author's institutional affiliation (academic vs. non-academic). The table shows that $79 \%$ of empirical articles and $81 \%$ literature reviews had academic first authors. However, the proportion of academic first authors was much lower in the case of descriptions of community programs (52\%) and theoretical articles (57\%).

The type of methodology used was analyzed for the 269 published empirical articles. Figure 3 shows that there has been a steady increase in the proportion of qualitative studies published over the years, accompanied by a steady decrease in the proportion of quantitative studies. In the most recent 5year period, the two types of methodology have been equally represented in CJCMH.

Areas of interest. Program evaluation $(n=79)$ and social action $(n=78)$ are the areas of interest present in the largest number of articles. Advocacy $(n=24)$, self-help $(n=16)$ and consultation $(n=0)$ are the areas of interest least present in $\mathrm{CJCMH}$. The popularity of the various areas of interest has varied considerably over time, as shown in Table 6. First of all, needs assessment appears to have been particularly popular between 1987 and 1991. Program evaluations experienced a surge between 1992 and 1996, while articles dealing with social action were less common in this period than in others. Self-help increased in popularity between 1987 and 1996, then disappeared completely. Public education and training were more likely to be present in the first 5 years than in the four subsequent periods. Finally, public responses to particular phenomena or group in the population declined between 1997 and 2001 and then made a strong comeback between 2001 and 2006, while the theme of advocacy has fallen almost to zero in the most recent 5-year period. 
Table 5

Proportion of First Authors with Academic Affiliation by Type of Article

\begin{tabular}{|c|c|c|c|c|}
\hline & $\begin{array}{l}\text { Academic } \\
\text { affiliation } \\
n=347\end{array}$ & $\begin{array}{l}\text { Non-academic } \\
\text { affiliation } \\
n=148\end{array}$ & $\chi^{2}$ & df \\
\hline Empirical $(n=269)$ & $79 \%$ & $21 \%$ & & \\
\hline Focus other than empirical & $59 \%$ & $41 \%$ & $23.18^{* *}$ & 1 \\
\hline Community program description $(n=42)$ & $52 \%$ & $48 \%$ & & \\
\hline Focus other than community program description & $72 \%$ & $28 \%$ & $6.88 * *$ & 1 \\
\hline Theoretical $(n=152)$ & $57 \%$ & $43 \%$ & & \\
\hline Focus other than theoretical & $76 \%$ & $24 \%$ & $19.14 * *$ & 1 \\
\hline Literature review $(n=32)$ & $81 \%$ & $19 \%$ & 203 & 1 \\
\hline Focus other than literature review & $69 \%$ & $31 \%$ & & \\
\hline
\end{tabular}

Note. $* * p<0.01$

Figure 3

Methodologies Used in Empirical Articles by 5-Year Period

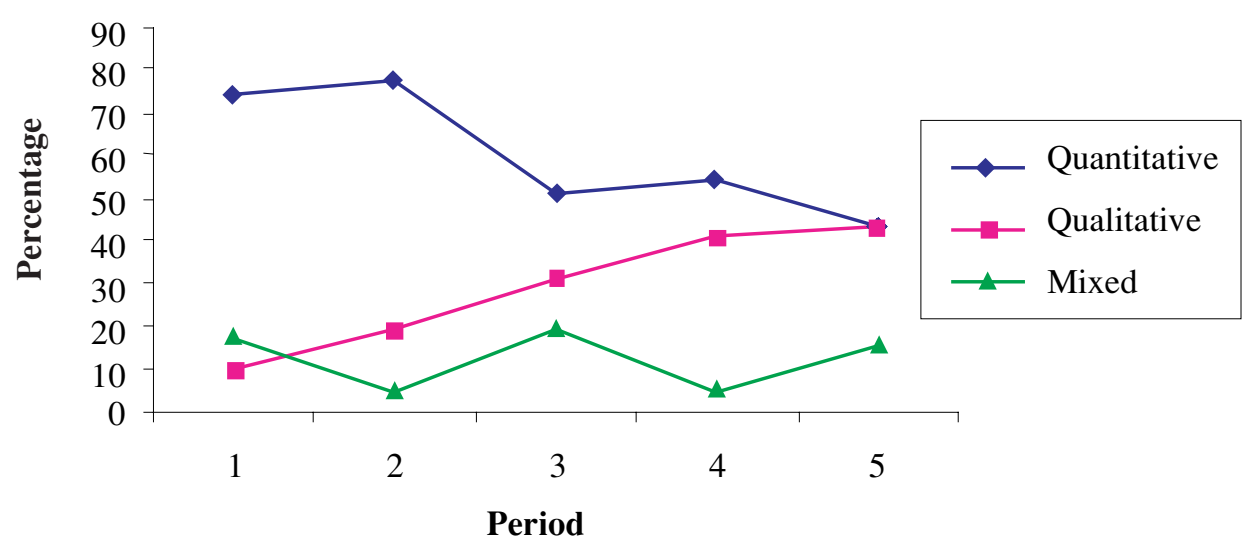

Note. $1=1982-86 ; 2=1987-91 ; 3=1992-96 ; 4=1997-2001 ; 5=2002-6$. 
Table 6

Areas of Interest Covered in CJCMH Articles by 5-Year Period

\begin{tabular}{|c|c|c|c|c|c|}
\hline & $\begin{array}{c}1 \\
n=123\end{array}$ & $\begin{array}{c}2 \\
n=95\end{array}$ & $\begin{array}{c}3 \\
n=101\end{array}$ & $\begin{array}{c}4 \\
n=85\end{array}$ & $\begin{array}{c}5 \\
n=91\end{array}$ \\
\hline Social service organization $(n=47)$ & $6 \%$ & $11 \%$ & $6 \%$ & $14 \%$ & $13 \%$ \\
\hline Program evaluation $(n=79)$ & $15 \%$ & $10 \%$ & $27 \%$ & $13 \%$ & $15 \%$ \\
\hline Assessment of community needs $(n=32)$ & $4 \%$ & $15 \%$ & $5 \%$ & $6 \%$ & $3 \%$ \\
\hline Community development $(n=25)$ & $6 \%$ & $7 \%$ & $3 \%$ & $7 \%$ & $2 \%$ \\
\hline Consultation $(n=0)$ & 0 & 0 & 0 & 0 & 0 \\
\hline Social action $(n=78)$ & $15 \%$ & $17 \%$ & $7 \%$ & $24 \%$ & $18 \%$ \\
\hline Self-help $(n=16)$ & 0 & $4 \%$ & $12 \%$ & 0 & 0 \\
\hline Public education and training $(n=25)$ & $15 \%$ & $2 \%$ & $2 \%$ & $2 \%$ & 0 \\
\hline Advocacy $(n=24)$ & $4 \%$ & $6 \%$ & $7 \%$ & $5 \%$ & $1 \%$ \\
\hline $\begin{array}{l}\text { Public response to a particular phenomenon } \\
\text { or group in the population }(n=45)\end{array}$ & $7 \%$ & $9 \%$ & $10 \%$ & $1 \%$ & $19 \%$ \\
\hline Other $(n=124)$ & $29 \%$ & $18 \%$ & $22 \%$ & $28 \%$ & $29 \%$ \\
\hline
\end{tabular}

Note. $1=1982-86 ; 2=1987-91 ; 3=1992-96 ; 4$ = 1997-2001; $5=2002-6$.

One quarter of the articles published did not specifically cover any of the themes identified in the CJCMH mission statement. Nor did they correspond to a "public response to a particular phenomenon or to a group in the population," a category that emerged in the course of the analysis. These articles generally covered more specific topics such as reintegration, addiction, violence, suicide, etc. The majority of these articles did contain a component related to mental health.

\section{Presence of Research Funding for Empirical Articles}

The majority of empirical articles published in CJCMH (57\%) did not mention any source of funding for conducting the research. The proportion of empirical articles for which a source of funding was identified varied according to the methodology used: $46 \%$ for quantitative studies, 39\% for qualitative studies, and $41 \%$ for those in which both methodologies were used. Table 7 shows the proportion of empirical articles in which research funding was present for each area of interest covered by CJCMH. Leaving aside the "self-help" and "public education and training" categories, which apply to a very small number of articles, research included in the "other" category appear to have been the most likely to be funded, closely followed by program evaluations. Next came studies on social action, needs assessments, and public responses to a particular phenomena or to a group in the population.

Between 1982 and 1986, only 19\% of empirical studies published in CJCMH mentioned a source of research funding. For the other periods, the proportion has been in the neighbourhood of $50 \%$. Figure 4 illustrates this trend. 
Table 7

Indication of Research Funding in Empirical Articles by Area of Interest

\begin{tabular}{lrr}
\hline & \multicolumn{2}{c}{ Research Funding } \\
\cline { 2 - 3 } & Yes & No \\
& $n=116$ & $n 3$ \\
\hline Social service organization $(n=12)$ & $25 \%$ & $75 \%$ \\
Program evaluation $(n=64)$ & $47 \%$ & $53 \%$ \\
Assessment of community needs $(n=22)$ & $41 \%$ & $59 \%$ \\
Community development $(n=8)$ & $25 \%$ & $75 \%$ \\
Consultation $(n=0)$ & 0 & 0 \\
Social action $(n=33)$ & $42 \%$ & $58 \%$ \\
Self-help $(n=6)$ & $50 \%$ & $50 \%$ \\
Public education and training $(n=2)$ & $100 \%$ & 0 \\
Advocacy $(n=6)$ & 0 & $100 \%$ \\
Public response to a particular phenomenon or group in the population $(n=37)$ & $41 \%$ & $59 \%$ \\
Other $(n=79)$ & $48 \%$ & $52 \%$ \\
\hline
\end{tabular}

Figure 4

Indication of Research Funding in Empirical Articles by 5-Year Periods

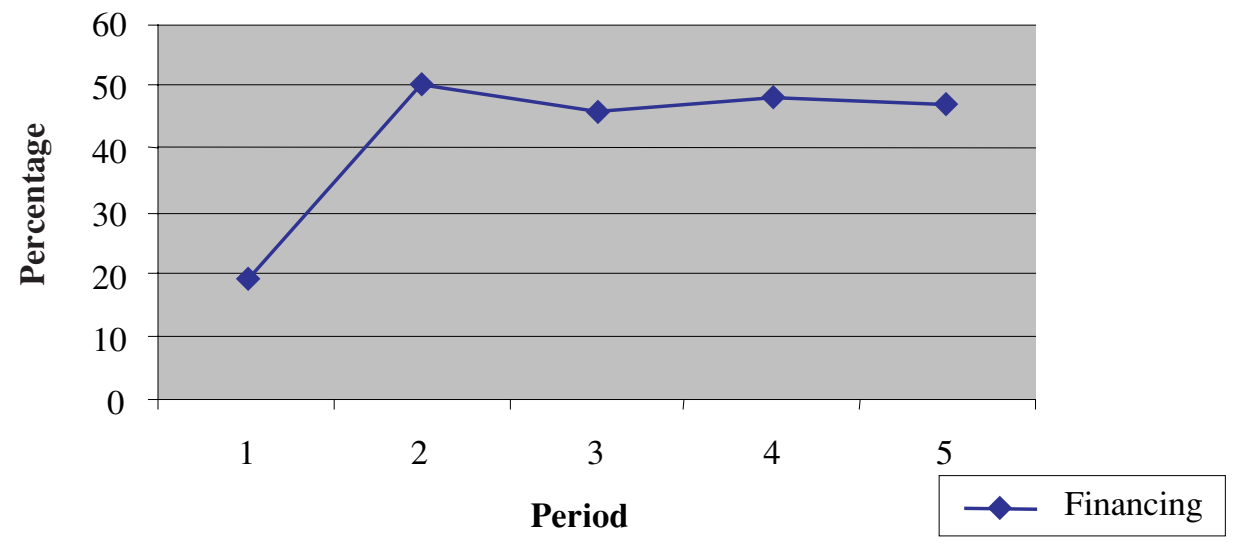

Note. $1=1982-86 ; 2=1987-91 ; 3=1992-96 ; 4=1997-2001 ; 5=2002-6$. 


\section{CONTENT ANALYSIS}

\section{DISCUSSION}

On the basis of the content analysis, a number of conclusions can be drawn about the "who" and the "what" of CJCMH. In terms of contributors to the Journal, it can be concluded that the people who have had the most influence on the Journal in the last 25 years (the editors and the most productive authors) have been academics and have included as many women as men. They have come from a variety of universities, located primarily in Quebec and Ontario and to a lesser extent in the Prairie Provinces and British Columbia. In addition, anglophones and francophones have been present among CJCMH authors in roughly the same proportions as in the Canadian population as a whole. In terms of the content in $\mathrm{CJCMH}$, it can be concluded that empirical articles have been predominant and that their proportion has increased in the most recent 5-year period, while there has been a marked decline in the proportion of theoretical articles. Among the empirical articles, those reporting the results of quantitative studies have been declining, while those in which a qualitative methodology is used have been increasing. With regard to the areas of interest represented in the articles, the most striking finding is that a quarter of CJCMH's output cannot be categorized in any of the areas specified in the Journal's mission statement. Those articles that can be categorized in the Journal's areas of interest are distributed in unequal proportions, with the distribution varying in different periods of the life of the Journal. Finally, for empirical articles published in 1987, research funding was indicated in roughly half of them.

The findings suggest that CJCMH has met the challenge of diversity, at least in part. The gender distribution of CJCMH's editors and most productive authors is a notable reflection of this equity. However, it should be noted that whether this conclusion applies to the entire group of authors whose work has been published in CJCMH cannot be verified on the basis of the examined data, and this constitutes a major limitation of the analysis in the area of gender. Equity can also be observed in the area of language of publication. English was the language most commonly used by authors, but the proportion of articles published in French (25.7\%) is comparable to the proportion of francophones in Canada (22.61\%) (Statistics Canada, 2001). While francophone authors were under-represented during CJCMH's first 5 years, since then the proportion of French-language articles has remained at a level that is representative of the proportion of francophones in Canada. Hence, CJCMH's selfidentification as a bilingual journal (Canadian Journal of Community Mental Health, 2001) appears legitimate. Equity is not as apparent in the location of first authors and editors, who have come predominantly from Ontario and Quebec. This is not surprising in light of the demographic weight of these two provinces within Canada, but better representation on the editorial team from elsewhere in Canada, and especially the Atlantic provinces, is a goal worth pursuing over the coming years.

Psychology appeared to be the most represented discipline in CJCMH, This may reflect the long empirical tradition in psychology. It is also possible that CJCMH meets a particular need for psychologists with a community orientation, since few academic journals in psychology encourage this perspective. Social work appears to be the second most influential discipline in CJCMH, while there has been very little representation from other disciplines. Again, it should be noted that these proportions were based on the analysis of the most influential authors only, excluding authors whose work has been published in the Journal, but who did not provide their specific discipline area. 
The most common institutional affiliations for first authors of articles published in CJCMH were universities. Even for most of the community program descriptions, the first author was affiliated with a university. These findings are consistent with the results of the earlier CJCMH content analysis (Peirson \& Walsh-Bowers, 1993). As Peirson and Walsh-Bowers suggest, the reason for the predominance of university affiliations among CJCMH authors could be the pressure to publish that prevails in universities. Another explanation could be that academics have more opportunity to publish since publication is recognized as part of their workload, which is not the case for practitioners. Even if this predominance is understandable, this tendency is paradoxical for CJCMH, whose mission statement states that it is a "forum for Canadian scholars and practitioners" (Canadian Journal of Community Mental Health, 2001).

The articles written by practitioners tended to be those that covered content related to practice. Such articles have been among the least common in CJCMH. ${ }^{1}$ This reflects the fact that CJCMH defines itself as an academic journal and a substantial majority of members of its peer review committees are academics. It may be difficult for practitioners who have little training in research and little awareness of the rigorous requirements for publication to meet academic standards. One potential way of increasing the number of authors who are practitioners would be to encourage them to publish in collaboration with academic researchers as co-authors whenever possible. In this way, a more practical perspective could be integrated into CJCMH's content, partnerships could be encouraged, and the contribution of practitioners to research theory could be accomplished.

Among empirical articles, those reporting the results of quantitative studies were in the majority. This can be explained by the dominant status that quantitative methods have traditionally enjoyed in some disciplines. Standards of reliability and validity that are expected in quantitative research have often served as criteria for judging the rigour of qualitative research, which is then considered less scientific (Bickman \& Rog, 1998). The fact that fewer qualitative than quantitative studies are published in a number of fields (Arredondo, Rosen, Rice, Perez, \& Tovar-Gamero, 2005; Fade, 2003; Kidd, 2002; Pope-Davis, Ligiero, Liang, \& Codrington, 2001) may be attributable to this tendency. In the case of CJCMH, it is important to place this finding in the context of the steady increase in the number of qualitative studies published and the parallel decline in the number of articles reporting quantitative studies. As a result of this trend, the number of qualitative studies has become equal to the number of quantitative studies in the Journal over the period 2002-2006. This reflects the growing popularity and recognition of qualitative methods, which have many advantages in community mental health research. The kinds of questions and data collection tools used in qualitative research make it possible for participants to describe themselves in their own words (Banyard \& Miller, 1998), allowing the voices of socially disadvantaged groups to be heard (Rudkin, 2003). This characteristic is consonant with two of the fundamental values of community mental health, participation and social justice (Liégeois \& Audenhove, 2005).

A large proportion of articles published in CJCMH did not cover any of the areas of interest identified in its mission statement. While a qualitative content analysis of these articles is beyond the scope of the present study, it could be a subject for further research. Such an analysis would make it possible to re-examine the boundaries of community mental health and to develop a more modern definition. The fact that these articles were published in CJCMH means that independent reviewers 


\section{CONTENT ANALYSIS}

and an editor agreed that the topic covered in the article was relevant and in conformity with the Journal's editorial policy. One important result of an in-depth analysis of the Journal's content could be closer agreement between CJCMH's content and its mission statement.

In articles that did relate to an area of interest identified in the mission statement, program evaluation was the most frequently covered theme. In general, the number of articles reporting program evaluations has increased in recent years (Feldman, 2004). According to Liégeois and Audenhove (2005), the importance of program evaluations in community mental health can be explained by the increasing emphasis that decision-makers place on programs' effectiveness and efficiency as they seek assurance that program funding is spent in accordance with these criteria. This development may explain the significant number of articles reporting the results of program evaluations in CJCMH.

Among the areas of interest identified in the mission statement, consultation was the theme that received the least coverage. Consultation is an activity in which a professional, exercising different roles and using appropriate strategies, interacts with a person, a group, an organization, or a community in the interest of modifying a situation (Laprise \& Payette, 2001). An earlier analysis showed that, overall, fewer than five studies per year were published in this area between 1961 and 1989. The studies on consultation that did appear during this period rarely dealt with mental health, especially between 1975 and 1989 (Fuchs, Fuchs, Dulan, Roberts, \& Fertstrom, 1992). Nevertheless, consultation is a widely practiced professional activity in a variety of settings, especially those associated with community mental health (Laprise \& Payette, 2001). In addition, consultation is related to fundamental values of community mental health: autonomy, which is sought by the organization that receives consultation, and support, which is provided through this practice (Liégeois \& Audenhove, 2005). Indeed, a process-oriented consultation model, which is often used in community settings, is intended to provide support for the setting, helping it achieve greater autonomy.

The explanation for the small number of articles in this area of interest may be that consultation is essentially an activity of practitioners, who are under-represented as authors in CJCMH. Practitioners often engage in consultation for other practitioners (Laprise \& Payette, 2001; Lescarbeau, Payette, \& St-Arnaud, 2003). Research on consultation presents a number of difficulties for researchers. Such research involves extensive planning with a large number of on-site participants in the consulting process. The researcher needs to observe consultants' practice, their effect on practitioners, and the subsequent practice of those practitioners with respect to the population. Since research on consultation involves the observation of indirect effects, it is more complex to research than other types of interventions (Fuchs et al., 1992).

Even though a special issue of CJCMH was devoted to self-help and support groups, self-help was the second least covered area of interest in CJCMH articles. This may be because self-help groups exclude practitioners by definition. They are also typically managed by people concerned with a particular difficulty (Lavoie, 2001). In this context, practitioners and researchers are often not in a position to observe these groups from the inside. In addition, a number of methodological difficulties have been identified regarding the study of these groups' impact on their members. In particular, it is difficult to do follow-up with participants because of their turnover rate during the course of the study. It is also difficult to study these groups in an experimental context (Lavoie \& Dufort, 1995). 
After consultation and self-help, the third least covered area of interest in articles published in CJCMH was advocacy. And yet, advocacy for the rights of people with severe mental illness has been identified as a key activity behind the emergence of the community mental health approach (Rosenberg \& Rosenberg, 2006). In 1963, U.S. President John F. Kennedy introduced the Community Mental Health Act and declared that mental health problems were rooted in social inequalities. This legislation provided for the funding of Community Mental Health Centers (Feldman, 2004; Kiely \& Moreau, 1975). Advocacy of rights for persons with severe mental illness remains an important preoccupation in community mental health, which includes among its fundamental values social justice, which refers to the equitable distribution of resources in society, and solidarity, which refers to concern for others and the common good (Liégeois \& Audenhove, 2005).

Most of the empirical studies published in CJCMH did not indicate the presence of research funding, even when the researchers who carried out these studies were affiliated with a university. This finding is surprising, given that research involves costs that can be substantial. However, it is difficult to know whether this absence means that the studies reported did not receive any research funding, or that authors did not report it as being present in their articles. Thus, there may be missing data in relation to this element in the analysis.

\section{STRENGTHS AND LIMITATIONS OF THE ANALYSIS}

There are limitations to the present content analysis which are important to mention. The quantitative content analysis was applied only to abstracts and some factual information accompanying articles, and in-depth information of a qualitative nature was not analyzed because of feasibility constraints. Nevertheless, the analysis did cover a large number and wide variety of dimensions, enabling an overall picture of CJCMH's published articles to be described. It was also possible to identify the ways in which the elements studied varied over time. In short, a comprehensive approach was favoured over a more detailed analysis.

Other limitations are attributable to the fact that some characteristics of the articles were not analyzed. For example, the fact that institutional affiliation was taken into account only for first authors limits the interpretation of findings. It is possible that the proportion of authors with a nonacademic institutional affiliation would have been different if all of the authors had been taken into consideration in the analysis. The lack of information regarding the sex and discipline of many authors prevented a full assessment of CJCMH's gender equity and interdisciplinary character. Another limitation of the study lies in the fact that all three members of the research team attend the same university, Université Laval, and are in the same field, community psychology. Thus, the homogeneity of the researchers does not reflect CJCMH's national and interdisciplinary character. On the other hand, this limitation only had minimal influence on data collection since most of the data collected were factual in nature. The researchers' affiliation at the same university facilitated the collaboration between them. Finally, the researchers were bilingual, which made them able to analyze all the articles published since 1982. 


\section{CONTENT ANALYSIS}

\section{CONCLUSION}

This content analysis suggests a number of future directions for consideration by CJCMH. Effort could be devoted to increasing the presence of some disciplines or geographical regions within the Journal, as well as the areas of interest that have received the least coverage in the articles-consultation, self-help, and advocacy - to the extent that $\mathrm{CJCMH}$ wishes to retain these areas of interest in its mission. This could be done through future special issues focusing on these areas. In addition, providing enhanced support for practitioners who submit articles may increase the diversity of topics published in the Journal, especially in areas that had the least coverage. It would also be worthwhile to reflect on the correspondence between the areas of interest identified in CJCMH's mission statement and the content of its articles. Some of the limitations of the present analysis could be overcome in future by collecting information on authors' sex and discipline. It would be worthwhile to take these dimensions into account in future analyses, as well as to deal more systematically with authors' geographical location, in the interest of being able to generalize the findings on these issues more fully.

In recent years a wave of modernism has swept over CJCMH, which has become an electronic journal starting with the Spring 2006 issue. There is no doubt other changes will occur over the next 25 years. We hope that the present analysis will serve as a foundation for reflection by future editorial teams as well as a useful monitoring tool for this publication, which remains unique in Canada.

\section{NOTE}

1. It should be pointed out, however, that some empirical articles, such as program evaluations, contain descriptives of programs.

\section{REFERENCES}

Arredondo, P., Rosen, D.C., Rice, T., Perez, P., \& Tovar-Gamero, Z.G. (2005). Multicultural counseling: A 10years content analysis of the Journal of Counseling \& Development. Journal of Counseling \& Development, 83, 155-161.

Austin, C.D., Des Camp, E., Flux, D., McClelland, R.W. \& Sieppert, J. (2005). Community development with older adults in their neighborhoods: The elder friendly communities program. Families in Society: The Journal of Contemporary Social Services, 86, 401-409.

Banyard, V.L., \& Miller, K.E. (1998). The powerful potential of qualitative research for community psychology. American Journal of Community Psychology, 26, 485-506.

Bennett, E.M., \& Trute, B. (1982). Editorial statement. Canadian Journal of Community Mental Health, 1, 2-4.

Bickman, L., \& Rog, D.J. (1998). Handbook of applied social research methods. Thousand Oaks, CA: Sage.

Buboltz,W.C., Miller, M., \& Williams, D.J. (1999). Content analysis of research in the Journal of Counseling Psychology (1973-1998). Journal of Counseling Psychology, 46, 496-503.

Buboltz, W., \& Savickas, M. (1994). A 20-year retrospective of the Career Development Quarterly. Career Development Quarterly, 42, 367-381.

Canadian Journal of Community Mental Health. (2001). Manual for the Canadian Journal of Community Mental Health. Waterloo, ON: Author.

Cokley, K., Caldwell, L., Miller, K., \& Muhammad, G. (2001). Content analysis of the Journal of Black Psychology (1985-1999). Journal of Black Psychology, 27, 424-438. 
Dufort, F. (2004). Évaluation psychosociale des milieux. Presentation in the course "Évaluation psychosociale des milieux" (Psychosocial assessment of communities). Sainte-Foy, QC: Université Laval.

Fade, S.A. (2003). Communicating and judging the quality of qualitative research: The need for a new language. Journal of Nutrition and Dietetics, 16, 139-149.

Feldman, S. (2004). Reflections on the 40th anniversary of the Community Mental Health Centers Act. Administration and Policy in Mental Health, 31, 369-380.

Fuchs, D., Fuchs, L., Dulan, J., Roberts, H., \& Fernstrom, P. (1992). Where is the research on consultation effectiveness? Journal of Educational and Psychological Consultation, 3, 151-174.

Howard, G.S., Cole, D.A., \& Maxwell, S.E. (1987). Research productivity in psychology based on publications in the journals of the American Psychological Association. American Psychologist, 42, 975-986.

Kidd, S.A. (2002). The role of qualitative research in psychological journals. Psychological Methods, 7, $126-138$.

Kiely, M.C., \& Moreau, D. (1975). Psychologie communautaire. Courrier-cours, 2, 1-14.

Laprise, R., \& Payette, M. (2001). Le choix d'un modèle de consultation selon une perspective communautaire. In F. Dufort \& J. Guay (Eds.), Agir au cœur des communautés: la psychologie communautaire et le changement social (pp. 187-216). Saint-Nicolas, QC: Presses de 1'Université Laval.

Lavoie, F. (2001). Les groupes de soutien et les groupes d'entraide. In F. Dufort \& J. Guay (Eds.), Agir au cœur des communautés: la psychologie communautaire et le changement social (pp. 157-181). Saint-Nicolas, QC: Presses de l'Université Laval.

Lavoie, F., \& Dufort, F. (1995). La recherche avec les groupes d'entraide: les difficultés méthodologiques et les défis. Canadian Journal on Aging, 14, 177-200.

L'Écuyer, R. (1990). Méthodologie de l'analyse développementale de contenu: méthode GPS et concept de soi. Sillery, QC: Presses de 1'Université du Québec.

Lescarbeau, R., Payette, M., \& St-Arnaud, Y. (2003). Profession: consultant. Montreal: Gaëtan Morin.

Liégeois, A., \& Audenhove, C.V. (2005). Ethical dilemmas in community mental healthcare. Journal of Medical Ethics, 31, 452-456.

Loveland, J.M., Buboltz, W.C., Schwartz, J., \& Gibson, G. (2006). Content analysis of CDQ from 1994-2003: Implications and trends for practitioners and researchers from a decade of research. Career Development Quarterly, 54, 256-264.

Morency, J., Couture, C., Johnson, C., \& Kiely, M.C. (1988). Vers la conceptualisation d'un modèle d'intervention en psychologie. Canadian Journal of Community Mental Health, 7, 81-88.

Mucchielli, A. (1996). Dictionnaire des méthodes qualitatives en sciences humaines et sociales. Paris: Armand Colin.

Novaco, R.W., \& Monahan, J. (1980). Research in community psychology: An analysis of work published in the first six years of the American Journal of Community Psychology. American Journal of Community Psychology, 8, 131-145.

Office québécois de la langue française (2002). Grand dictionnaire terminologique. Quebec, QC: Government du Québec. Retrieved January 5, 2007, from: http://www.granddictionnaire.com/btml/fra/r_motclef/ index 1024_1.asp20

Ouattara, C. (2003, June). Développement communautaire et réduction de la pauvreté dans un contexte de décentralisation. Paper delivered to ENDSA Seminar. Retrieved January 5, 2007, from: http://unpan1.un.org/ intradoc/groups/public/documents/UN/UNPAN011027.pdfin

Peirson, L., \& Walsh-Bowers, R. (1993). The first decade of the Canadian Journal of Community Mental Health: A critical review. Canadian Journal of Community Mental Health, 12(1), 23-35.

Pope-Davis, D.B., Ligiero, D.P., Liang, C., \& Codrington, J. (2001). Fifteen years of the Journal of Multicultural Counseling and Development: A content analysis. Journal of Multicultural Counseling and Development, 29, 226-238.

Posavac, E.J., \& Carey, R.G. (2003a). The assessment of need. In E.J. Posavac \& R.G.Carey (Eds.), Program evaluation: Methods and case studies (pp. 114-131). Upper Saddle River, NJ: Prentice Hall.

Posavac, E.J., \& Carey, R.G. (2003b). Program evaluation: An overview. In E.J. Posavac \& R.G. Carey (Eds.), Program evaluation: Methods and case studies (pp. 1-22). Upper Saddle River, NJ: Prentice Hall. 


\section{CONTENT ANALYSIS}

Rosenberg, J., \& Rosenberg, S. (2006). Introduction conceptualizing the challenges in community mental health. In J. Rosenberg \& S. Rosenberg (Eds.), Community mental health: Challenges for the 21 st century (pp. 16). New York: Routledge.

Rudkin, J.K. (2003). Community psychology: Guiding principles and orienting concepts. Upper Saddle River, NJ: Prentice Hall.

Statistics Canada. (2001). Detailed mother tongue (160), sex (3), knowledge of official languages (5) and age groups (15) for population, for Canada, provinces, territories, census metropolitan areas and census agglomerations, 1996 and 2001 censuses-20\% sample data. Ottawa: Government of Canada.

Wakefield, S.E.L., \& Poland, B. (2005). Family, friend or foe?: Critical reflections on the relevance and role of social capital in health promotion and community development. Social Science \& Medicine, 60(12), 28192832. 


\section{APPENDICES}

\section{Coding Table (Original)}

\begin{tabular}{|c|c|}
\hline Année & \\
\hline Volume & \\
\hline Numéro & \\
\hline Titre de l'article & \\
\hline Pages & \\
\hline Auteur-e-s & \\
\hline $\begin{array}{l}\text { Affiliation institutionnelle } \\
1^{\text {erère }} \text { auteur-e }\end{array}$ & \\
\hline Langue de l'article & Français \\
\hline Type d'article & Empirique, théorique, recension d'écrits, communautaire pratique \\
\hline $\begin{array}{l}\text { Si empirique, type de } \\
\text { méthodologie: }\end{array}$ & $\begin{array}{l}\text { - qualitatif } \\
\text { - quantitatif } \\
\text { - mixte (qualitatif et quantitatif) }\end{array}$ \\
\hline $\begin{array}{l}\text { Domaine d'intérêt énoncé dans la } \\
\text { mission de la RCSMC: }\end{array}$ & $\begin{array}{l}\text { L'organisation des services sociaux, l'évaluation de programmes, } \\
\text { l'analyse des besoins de la communauté, le développement } \\
\text { communautaire, l'action sociale, l'entraide, l'éducation communautaire et } \\
\text { la formation, la consultation et la défense de droits et d'intérêts. Préciser } \\
\text { si autre. }\end{array}$ \\
\hline $\begin{array}{l}\text { Mention de financement des } \\
\text { recherches empiriques publiées: }\end{array}$ & Oui Non \\
\hline
\end{tabular}




\section{CONTENT ANALYSIS}

\section{Coding Table (Translation)}

\begin{tabular}{|c|c|}
\hline Year & \\
\hline Volume & \\
\hline Number & \\
\hline Title of article & \\
\hline Pages & \\
\hline Authors & \\
\hline $\begin{array}{l}\text { Institutional affiliation } \\
1 \text { st author }\end{array}$ & \\
\hline Language of article & English \\
\hline Type of article & Empirical, theoretical, literature review, community program description \\
\hline $\begin{array}{l}\text { If empirical, type of } \\
\text { methodology: }\end{array}$ & $\begin{array}{l}\text { - qualitative } \\
\text { - quantitative } \\
\text { - mixed (qualitative and quantitative) }\end{array}$ \\
\hline $\begin{array}{l}\text { Area of interest specified in the } \\
\text { CJCMH mission statement: }\end{array}$ & $\begin{array}{l}\text { Social service organization, program evaluation, assessment of } \\
\text { community needs, community development, social action, self-help, } \\
\text { public education and training, consultation, and advocacy. Specify } \\
\text { if other. }\end{array}$ \\
\hline $\begin{array}{l}\text { Indication of research funding for } \\
\text { published empirical research: }\end{array}$ & Yes No \\
\hline
\end{tabular}




\section{Definitions of Types of Articles}

Description of a community program: The article describes the implementation of a program or intervention in the community mental health field (Novaco \& Monahan, 1980; Peirson \& Walsh-Bowers, 1993).

Empirical: The article presents results on data collected to answer research questions (Novaco \& Monahan, 1980). An empirical article can be based on quantitative data, when the data are numerical in nature; an article can be based on qualitative data, when the data are textual in nature; an empirical article can be based on mixed data, when both kinds of data are present.

Literature review: The article presents a systematic review of research findings on a specific subject. New ideas may be introduced, but the primary emphasis is on reviewing existing publications (Novaco \& Monahan, 1980).

Theoretical: The article introduces new ideas or concepts or refines existing ideas or concepts (Peirson \& Walsh-Bowers, 1993). It emphasizes particular issues related to these ideas or concepts. While it may refer to other ideas and studies to put these ideas and concepts into context, its primary emphasis is not on reviewing the literature but on new or newly refined ideas and concepts (Novaco \& Monahan, 1980).

\section{Definitions of Themes Relating to CJCMH's Mission Statement}

Advocacy: Promotion for the improvement in living conditions of socially disadvantaged groups to ensure fundamental rights and achieve greater social justice.

Assessment of community needs: Detailed examination of the essential elements (Dufort, 2004) that people need to have to be in a satisfactory state (Posavac \& Carey, 2003a).

Community development: Voluntary initiative, often by marginalized groups (Austin, Des Camp, Flux, McClelland, \& Sieppert, 2005), aimed at improving their living conditions, especially through the development of interventions relating to health, education, and greater local democracy (Ouattara, 2003).

Consultation: Type of intervention in which a practitioner, exercising different roles and using appropriate strategies, interacts with a person, a group, an organization, or a community in the interest of modifying a situation (Laprise \& Payette, 2001).

Program evaluation: Use of research methods to determine whether a human service is needed, whether the way in which it is provided is adequate to meet the needs that have been identified, whether it is provided as anticipated, and whether it helps meet the needs at a reasonable cost and without unacceptable side-effects (Posavac \& Carey, 2003b). 


\section{CONTENT ANALYSIS}

Public education and training: Interventions that increase a community's knowledge and that develop its skills in order to better address issues that it encounters (Office québécois de la langue française, 2002).

Public response to a particular phenomenon or to a group in the population: Attitudes of a person or group towards an event or towards another person or group (Office québécois de la langue française, 2002).

Self-help: Reciprocal activity amoung a group of people showing information and social support.

Social action: Form of community development (Wakefield \& Poland, 2005) in which a collective action is taken with the aim of changing public policy (Office québécois de la langue française, 2002).

Social service organization: Organization that sets out to achieve specific goals (Office québécois de la langue française, 2002) in the health and social services field. Such an organization may or may not be government funded and administered .

Other: Impossible to classify in any of the existing categories. 